\title{
Production of Solid Soap with Addition of Green Betal Leave (Piper Betle L.) Extract and Left Lemon Extract(Cymbopogon Nardus L. Rendle) As Antioxidants
}

\author{
Martha Aznury ${ }^{1, *}$ Ahmad Zikri ${ }^{1}$ Aisyah Suci Ningsih ${ }^{1}$ Elina Margaretty ${ }^{1}$ \\ Liona Agriani ${ }^{1}$ Indriani Indriani ${ }^{1}$ Nova Rachmadona ${ }^{2}$
}

\author{
${ }^{1}$ Department of Chemical Engineering, Politeknik Negeri Sriwijaya, Palembang, Indonesia \\ ${ }^{2}$ Department of Chemical Science and Engineering, Graduate School of Engineering, Kobe University, Japan \\ ${ }^{*}$ Corresponding author. Email: martha_aznury@polsri.ac.id
}

\begin{abstract}
Soap is one type of surfactant made from natural oils or fats. The saponification procedure produces soap. Soap serves to emulsify dirt in the form of oil or other impurities. Many soaps sold in the market use synthetic additives as antioxidants that can interfere with skin health for those with sensitive skin. The scarcity of soap that uses antioxidants causes the high price of soap that contains antioxidants. This problem can be solved by using existing natural resources such as using green betel leaves and citronella and producing natural antioxidant-dense soap. This study aims to determine the composition of palm oil, olive oil, and virgin coconut oil (VCO) on the quality of making solid soap and obtain variations of solid soap with green betel leaf extract and citronella by the Indonesian National Standard (SNI) 06-3532-1994. The method used is by varying the oil, green betel leaf extract, and citronella. Product analysis includes $\mathrm{pH}$, water content, free alkali, free fatty acid, mineral oil, bacterial test, and organoleptic test. The natural antioxidant of the soap products obtained good results from a mixture of palm oil, VCO oil, and olive oil in a ratio of $1: 2: 2$.
\end{abstract}

Keywords: Antioxidants, Green Betel Leaf, Soap, Fragrant Lemongras

\section{INTRODUCTION}

Nowadays, many soaps sold in the market use synthetic additives as antioxidants that can interfere with skin health for those with sensitive skin. Besides, there are still very few antioxidant soaps on the market, even though antioxidants function as free radical scavengers-skin due to an unhealthy environment anymore by pollution, especially air pollution. Some of the ingredients that contain lots of natural antioxidants are green betel leaves and citronella leaves. So that green betel and citronella are used as natural antioxidants in making solid soap.

Betel leaf has many beneficial ingredients, and green betel leaf extract contains 31 compounds [1]. The main components are eugenol (25.03\%); 2,5-dimethyl benzoic acid (12.08\%); decahydro-4amethyl-1-methyleneyl naphthalene (7.18\%); 1,2,3,4,5,6,8 aoctahydro-7-methyl naphthalene
(8.36\%); and methyl naphthalene (13.43\%). The content of phenol (carvacrol) and phenylpropane (eugenol and kavikol) in green betel leaf essential oil can be functions as an antiseptic [2].

Lemongrass plants contain essential oils or essential oils. The essential oil from lemongrass leaves averages $0.7 \%$ (about $0.5 \%$ in the rainy season and can reach $1.2 \%$ in the dry season). Distilled citronella oil is pale yellow. The main active ingredients produced are aldehyde compounds (citronellol- $\mathrm{C}_{10} \mathrm{H}_{6} \mathrm{O}$ ) of $30-45 \%$, alcohol compounds (citronelol- $\mathrm{C}_{10} \mathrm{H}_{20} \mathrm{O}$ and geraniol- $\mathrm{C}_{10} \mathrm{H}_{18} \mathrm{O}$ ) of 55$65 \%$, and other compounds such as geraniol, citral, nerol, metal, heptonon. and dipentene [3]. The roots of the lemongrass plant contain approximately $0.52 \%$ of the alkaloids of $300 \mathrm{~g}$ of plant material. In addition, the leaves and roots of the lemongrass plant contain flavonoids, namely luteolin. Other flavonoid compounds isolated from the lemongrass plant aerial parts are quercetin, kaempferol, and apigenin [4], so 
they are very suitable as antioxidant additives in soap making.

Antioxidant compounds are bioactive compounds that are widely found in plants. These compounds can be in flavonoids, alkaloids, tannins, and glycosides [5]. Green betel chemistry contains essential oils, flavonoids, alkaloids, tannins, and polyphenolic compounds. Although lemongrass is used as a medicinal plant, empirically, it is used for treatment, including kariofilen, antifungal, antiinflammatory, and antitumor as an anesthetic. The chemical content of citronella is essential oil, citronellal, geraniol, mircen and nerol [6].

The saponification reaction using alkali is the reaction of triglycerides with alkali $(\mathrm{NaOH}$ or $\mathrm{KOH})$ to produce soap and glycerin. Soap is made by saponification of fats or oils using an alkaline solution. The commonly used alkaline solution is $\mathrm{NaOH}$ and $\mathrm{KOH}$. If the base used is $\mathrm{NaOH}$, then the reaction product is hard soap (solid), while the base used is $\mathrm{KOH}$, then the reaction product is liquid soap.

In the market, solid soap is more often used by the general public. Besides, the price is more economical compared to other types of soap. Moreover, the glycerin content is not much lost. Therefore, soap circulating in the market containing glycerin has been widely used as a basic ingredient for making biodiesel, cosmetic ingredients, medicines, and toothpaste. Glycerin or glycerol $\left(\mathrm{C}_{3} \mathrm{H}_{5}(\mathrm{OH})_{3}\right)$ is a by-product of the saponification reaction, namely the reaction of soap formation. The function of glycerin in soap is to moisturize the skin [7]

\section{MATERIAL AND METHOD}

Green betel leaf (Piper betel L.) and citronella (Cymbopogon nardus L. Rendle) were taken from the Palembang area with the characteristics of young leaves as much as \pm 500 grams. The treatment is carried out on green betel leaves and citronella. First, it washed the green betel leaves and citronella, then finely chopped, after that, it extracted 150 grams of green betel leaves and citronella, which were cut with $96 \%$ ethanol solvent.

The raw material, where the oil used three types are namely palm cooking oil (PCO), virgin coconut oil (VCO), and olive oil.
Table 1. Solid Bath Soap Formulation Variations Green Betel Leaf Extract and Fragrant Lemongrass

\begin{tabular}{|l|c|c|c|c|c|c|c|}
\hline \multirow{2}{*}{ Materials } & \multicolumn{7}{|c|}{ Sample } \\
\cline { 2 - 8 } & 1 & 2 & 3 & 4 & 5 & 6 & \\
\hline $\begin{array}{l}\text { Betel leaf } \\
\text { extract }\end{array}$ & 0 & 1.5 & 0 & 2.5 & 1.5 & 2.5 & 3.5 \\
\hline $\begin{array}{l}\text { Citronella } \\
\text { extract }\end{array}$ & 1.5 & 0 & 2.5 & 0 & 1.5 & 2.5 & 3.5 \\
\hline Palm oil & 10 & 10 & 10 & 10 & 10 & 10 & 10 \\
\hline Olive oil & 20 & 20 & 20 & 20 & 20 & 20 & 20 \\
\hline VCO oil & 20 & 20 & 20 & 20 & 20 & 20 & 20 \\
\hline $\begin{array}{l}\text { NaOH } \\
(30 \%)\end{array}$ & 15 & 15 & 15 & 15 & 15 & 15 & 15 \\
\hline
\end{tabular}

The method used in this research is experimental collection and using the method of observation and analysis of data processing is done with statistics. Making antioxidant soap of green betel leaf and citronella is done by varying the volume of oil and extracts of green betel leaf and citronella.

\section{RESULT AND DISCUSSION}

\subsection{Extraction and Identification of Green Betel Leaf and Fragrant Lemongrass}

Extraction of green betel leaf and citronella was carried out by the soxhlet extraction method by extracting 150 grams of green betel leaf and citronella in $600 \mathrm{ml}$ of $96 \%$ ethanol for 4 hours. The results of the green betel leaf extract are blackish green and have a distinctive green betel odor, while the results of the citronella extract are yellow and have a distinctive smell of citronella. Ethanol has a similar polarity to phenol, so it is suitable as a solvent in the extraction process of green betel leaf and citronella.

After the extraction process, $250 \mathrm{ml}$ of extract was obtained with a neutral $\mathrm{pH}$ of 7 from 150 grams of green betel leaf and citronella. The yield was $87.77 \%$. The high water content is caused because before the green betel leaf is extracted with ethanol, the green betel leaf is not dried in the sun. The preliminary test shows that the extract obtained is brownish yellow, smells good, and contains tannins, flavonoids, triterpenoids, essential oils, and phenols that are alcohol-like, so they are often used as disinfectants. The antibacterial effect of betel leaf is due to the presence of compounds such as phenols that change the protein properties of bacterial cells so that the permeability of the bacterial cell wall increases and 
the bacteria becomes lysed. In addition, flavonoids disrupt the integrity of bacterial cell membranes [8].

\subsection{Analysis of Natural Antioxidant Solid Soap Extract of Green Betel Leaf and Fragrant Lemongrass}

In the manufacture of solid antioxidant soap, the active ingredients of green betel leaf extract and citronella are added. Green betel leaf extract is useful as an antioxidant, anti-inflammatory and disguises rancid odor in soap. At the same time, citronella extract is very useful as an antioxidant, antiinflammatory, anticancer, and immunomodulator. In this study, the variables used were variations in oil composition and variations in the addition of green betel leaf extract, which affected the quality of solid soap, which included $\mathrm{pH}$, water content, free alkali content, free fatty acid content, and mineral oil which referred to the SNI 06-3532 1994 standard test method

\subsection{Oil Composition}

Before getting the results according to SNI 063532-1994, research was carried out by varying the three types of oil. The formulations used are A1 (3:1:1) grams, A2 (1:2:2) grams, A3 (2:1:2) grams, and A4 (2:2:1) grams. The graph of the composition of the oil in the manufacture of antioxidant soap can be seen in Figure 1

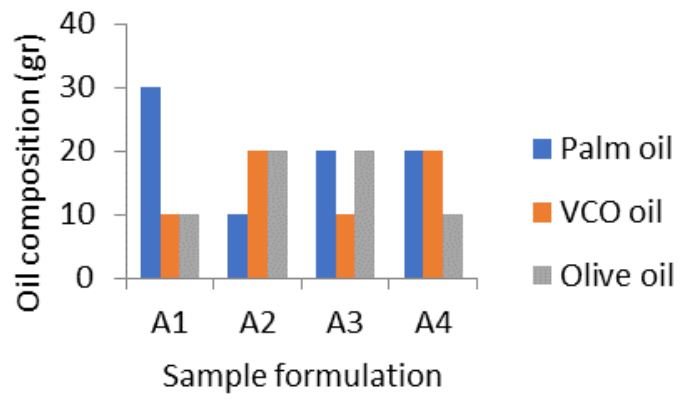

Figure 1 Variations in Oil Composition

The lowest results were obtained and following SNI 06-3532-1994, namely formulation A2 with a $\mathrm{pH}$ value of 10 where the $\mathrm{pH}$ according to SNI 06-35321994 was 9.8 to 10 , the water content value was $13 \%$ with a water content according to SNI 06- 3532-1994 $\max 15 \%$, free alkali content value of $0.056 \%$ with free alkali content according to SNI 06-3532-1994 $\max 0.1 \%$, the value of free fatty acid content with free fatty acid content according to SNI 06-3532-1994 $\max 2,5 \%$ and negative mineral oil.

\subsection{Formulation of Green Betel Leaf Extract and Fragrant Lemongrass}

In the study of making solid soap with the addition of green betel leaf extract and citronella with the formulations A21 (0:1.5) gram, A22 (1.5:0) gram, A23 (0:2.5) gram, A24 (2, 5:0), A25 (1.5:1.5) grams, A26 (2.5:2.5) grams, and A27 (3.5:3.5) grams. The graph of the formulation of green betel leaf extract and citronella can be seen in Figure 2

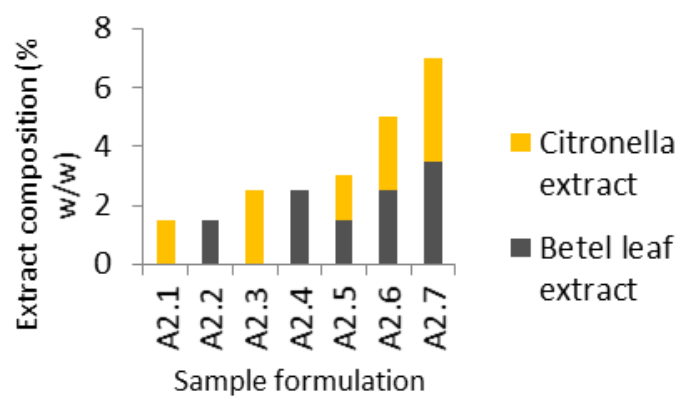

Figure 2 Green Betel Leaf Extract and Fragrant Lemongrass Extract Formula

From the graph above, green betel leaf extract and citronella are addictive substances used to make solid antioxidant soap with a soap formulation with various oils tested for quality and according to SNI 06-35321994, namely formulation A2 with a ratio of oil (1: $2: 2$ ).

\section{5 pH Test}

The $\mathrm{pH}$ test is a chemical test that aims to determine the acidity or alkalinity of solid soap. The $\mathrm{pH}$ test was carried out because $\mathrm{pH}$ is one of the important parameters to see the stability of solid soap during storage and to determine the stability of the $\mathrm{pH}$ of each solid soap formula made by the $\mathrm{pH}$ or not because if it is not by the $\mathrm{pH}$ of the skin, it will cause irritation if it is too acidic, and can cause scaly and itchy skin if it is too alkaline. Based on SNI 06-35321994, solid soap marketed in the community has a $\mathrm{pH}$ value of 9 to 10.8. The oil composition formulation and its effect on $\mathrm{pH}$ can be seen in Figure 3 


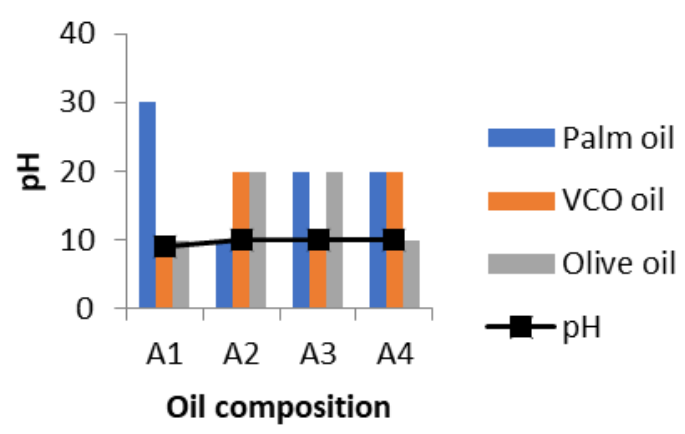

Figure 3 Effect of Oil Composition on $\mathrm{pH}$

In the formulation with the influence of the composition of palm oil (Fortune), VCO oil (VCO sultan), and olive oil (Afra), the $\mathrm{pH}$ values obtained met the standards of 9 and 10 due to the constant concentration of alkali $(\mathrm{NaOH})$ used at $30 \%$, so that the resulting $\mathrm{pH}$ does not change significantly.

The graph of the effect of adding green betel leaf extract and citronella to the $\mathrm{pH}$ of solid soap is shown in Figure 4 below:

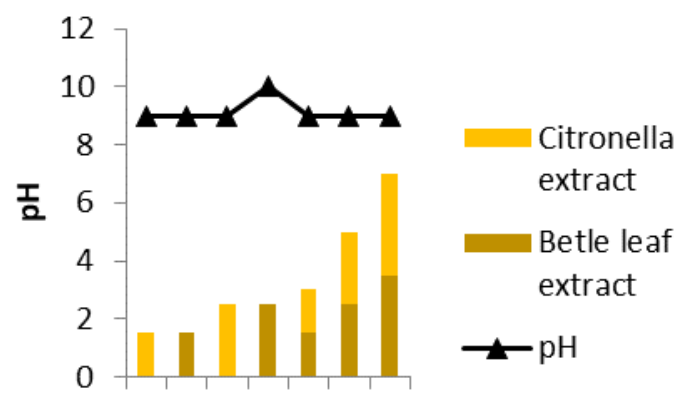

A2.1 A2.3 A2.5 A2.7

Sample formulation

Figure 4 Effect of Variations in Addition of Green Betel Leaf Extract and Fragrant Lemongrass on $\mathrm{pH}$

From the graph, solid soap with green betel leaf extract and citronella has a $\mathrm{pH}$ following the maximum standard of SNI 1994, namely the $\mathrm{pH}$ value obtained in the range of $\mathrm{pH} 9$ and 10 . Soap with a high $\mathrm{pH}$ can increase the growth of bacterium bacteria and make the skin dry because soap with a high $\mathrm{pH}$ can swell the keratin making it easier for bacteria to enter, which causes the skin to become dry and cracked. At the same time, soap with a too low $\mathrm{pH}$ can cause skin irritation [9].

\subsection{Effect of Oil Composition and Variable Addition of Green Betel Leaf Extract and Fragrant Lemongrass on Solid Soap on Water Content}

Water content is the amount of water contained in the material expressed in percent. For example, the maximum water content in soap is $15 \%$ since the water content affects the hardness of solid soap [10] In addition to affecting the hardness of soap with increased water content, it can accelerate the growth of microbes in the soap itself and affect the shelf life of soap that does not last long.

The formulation of oil composition and its effect on water content can be seen in Figure 5 below:

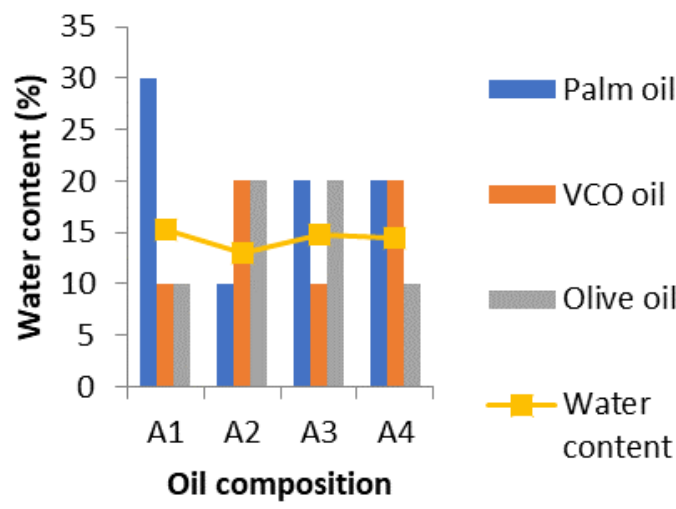

Figure 5 Effect of Oil Composition on Water Content

The effect of oil composition on the water content in solid soap obtained the best formulation, namely the A2 formula, because the water content obtained from the analysis was smaller than the other formulations, namely $13 \%$. In the formula, the amount of palm oil used is less, so the water content in solid soap is lower than the others, in the A1 3:1:1 formulation, where the largest amount of palm oil, the moisture content obtained is $15.2 \%$ because the palm oil used is not palm cooking oil sold in the market and has been given other ingredients. Another addition is A3 with a composition of 2:1: 2 where the amount of palm oil used is as much as VCO, the water content produced is $14.8 \%, \mathrm{~A} 4$;with a composition of $2: 2: 1$ is obtained with a water content of $14.4 \%$, which is still meet the standards of SNI 06-3532-1994.

While in the variation of the addition of green betel leaf extract, the water content is directly proportional to the amount of extract added, the more the addition of the extract, the higher the water content in solid soap. The addition of green betel leaf extract and citronella, there are 7 samples for sample A21 (0:1.5) gr, sample A22 (1.5:0) gr, sample A23 (0:2.5) gr, sample A24 (2,5:0) gr, sample A25 (1.5:1.5), 
sample A26 (2.5:2.5), and sample A27 (3.5:3.5) gr. The graph of the effect of adding green betel leaf extract and citronella to solid soap on water content can be seen in Figure 6 below:

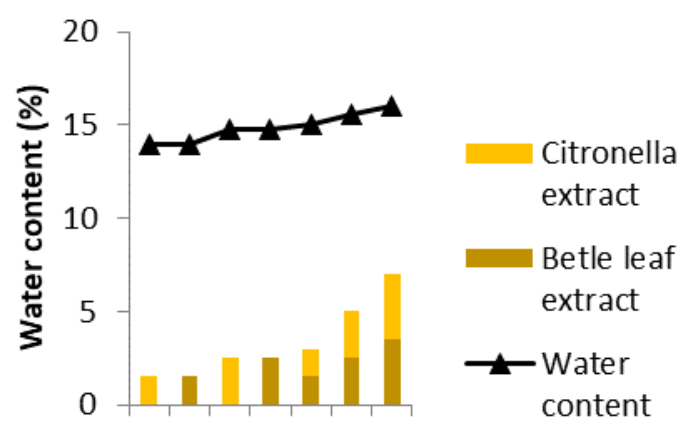

A2.1 A2.3 A2.5 A2.7

Sample formulation

Figure 6 Effect of Variations in Addition of Green Betel Leaf Extract and Fragrant Lemongrass on Water Content

From the graph, it can be seen that solid soap with the addition of green betel leaf extract and citronella in samples A21, A22, A23, A24, A25 has a water content according to SNI 06-3532-1994, namely 14\%, $14 \%, 14.8 \%, 14.8 \%$, and $15 \%$. Meanwhile, samples A26 and A27 did not meet the water content standards according to SNI 06-3532-1994, namely $15.6 \%$ and $16 \%$, respectively. Water content can affect the solubility of soap in water when used. If the water content in the soap is too high, it will cause the soap to shrink easily and become uncomfortable when used. Moisture content can also affect the hardness of solid soap. The higher the water content of the soap, the softer the soap will be. Conversely, the lower the water content of the soap, the harder the soap will be. The increase in water content can be caused by adding raw materials such as oil and extracts [11].

\subsection{Effect of Oil Composition and Variations in Addition of Green Betel Leaf Extract on Free Alkali Levels in Solid Soap}

Free alkali is an alkali in soap that is not bound as a compound. The excess of free alkali in soap should be less than $0.1 \%$ for $\mathrm{NaOH}$ soap and $0.14 \%$ for $\mathrm{KOH}$ soap. Alkalis are harsh and irritate the skin. Excessfree alkali in soap can be caused by full or excessive alkali concentrations in the saponification process.

The formulation of the oil composition and its effect on the free alkali content can be seen in Figure 7 below:

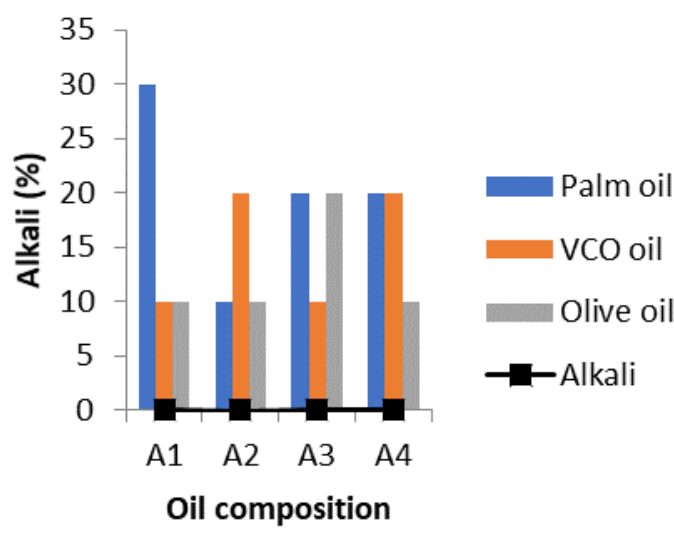

Figure 7 Effect of Oil Composition on Free Alkali Levels

Based on the research and analysis done, the manufacture of solid soap with oil composition in formula A2 has the lowest free alkali content of $0.056 \%$ because $\mathrm{NaOH}$ reacts well to oil mixtures. However, the formulations A1, A2, and A4 also still meet SNI 06-3532-1994 solid soap. The graph of the Effect of Adding Green Betel Leaf Extract and Fragrant Lemongrass on Making Solid Soap is shown in Figure 8 below:

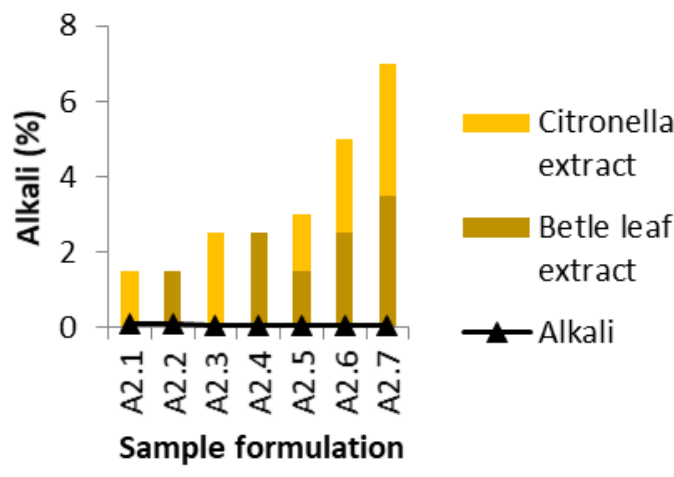

Figure 8 Effect of Addition of Green Betel Leaf Extract on Free Alkali Levels

In the addition of green betel leaf extract and citronella, the higher the addition of the extract, the lower the alkali content. Therefore, it is indicated that green betel leaf extract and citronella contain phenols. Phenol in green betel leaf extract is an alcoholic compound that functions as a natural antioxidant soluble in acetone, alcohol, glacial acetic acid, and alkali hydroxide [12]. Because phenol is soluble in alkali hydroxide, this is what causes the addition of green betel leaf extract. Citronella in the manufacture of solid soap can cause a decrease in alkali because it can dissolve well with alkali in soap, in each sample formulation A21, A22, A23, A24, and A25, A26, A27 
free alkali content meets the standard of SNI 06-35321994 solid soap.

\subsection{Effect of Oil Composition and Variations in Addition of Green Betel Leaf Extract and Fragrant Lemongrass on Free Fatty Acid Levels in Solid Soap}

In soap, free fatty acids are not bound to sodium or triglyceride compounds (neutral fats). Therefore, the high free fatty acids in soap will reduce the cleaning power of soap because soap that should emulsify dirt will emulsify free fatty acids first so that the use of soap becomes less effective. In addition, the hydrolysis reaction can cause damage to oil or fat, resulting in damage to this oil or fat due to the presence of water in the oil or fat, which causes rancidity with changes in the taste and smell of the oil. Determining the formulation of oil composition and its effect on free fatty acid levels can be seen in Figure 9 below:

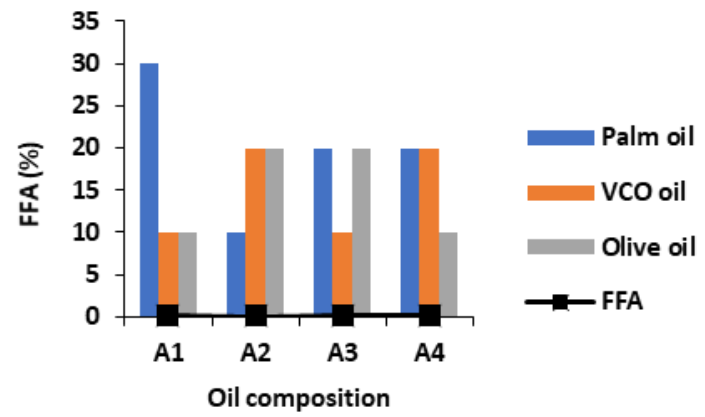

Figure 9 Effect of Oil Composition on Free Fatty Acid Content

On the influence of the composition of the oil formulation, A2 with an oil composition of 1:2:2 has the lowest free fatty acid content of $0.1025 \%$. A good hydrolysis reaction between triglycerides and water can make more free fatty acids involved in saponification so that the free fatty acids produced are low. While in samples A1, A3, and A4, the fatty acids produced were larger. Higher free fatty acids cause a rancid odor. Free fatty acid is one of the important parameters. SNI 06-3532-1994 stipulates the free fatty acid content in soap must be $<2.5 \%$. Soap samples A1, A2, A3, and A4 levels of free fatty acids still meet the quality standards of SNI 06-3532-1994. The graph of the effect of adding green betel leaf extract and citronella to free fatty acid levels can be seen in Figure 10

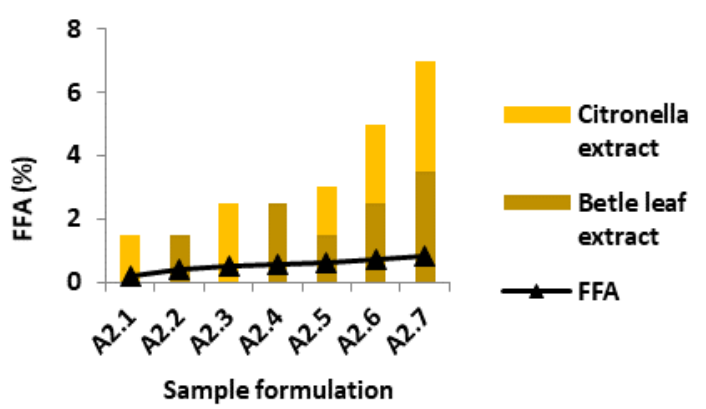

Figure 10 Effect of Variations in Addition of Green Betel Leaf Extract and Fragrant Lemongrass on Free Fatty Acid Levels

In the variation of addition of green betel leaf extract and citronella, the higher the addition of green betel leaf extract and citronella, the higher the free fatty acid content. The addition of good extracts to soap preparations to overcome the excess of free fatty acids is the addition of 1,2 , and $3 \%$ extracts. In the addition of green betel leaf extract and citronella, it can be analyzed that the higher the addition of the extract, namely $2.5 \%$ - 7\% in samples A23, A24, A25, and $\mathrm{A} 26, \mathrm{~A} 27$, the free fatty acid content is higher, this occurs because of the hydrolysis process between triglycerides with water to produce glycerol and free fatty acids. So that the higher the addition of extract in the soap sample, the higher the free fatty acid content. The levels of free fatty acids in the formulations A21, A22, A23, A24, and A25, A26, A27 met the soap standard based on SNI, meaning that the soap obtained was effectively used.

\subsection{Effect of Oil Composition and Variations in Addition of Green Betel Leaf Extract and Fragrant Lemongrass on Mineral Oil Content in Solid Soap}

Mineral oil is a substance or material that remains as oil, but when water is added, an emulsion will occur between water and oil, characterized by turbidity [13]. The addition of green betel leaf extract and citronella in samples A21, A22, A23, A24, A25, A26, and A27 mineral oil was negative. It is indicated by the time of sample testing. The sample does not show turbidity when titrated with water, so that the sample is negative for mineral oil. Negative mineral oil indicates no more harmful oil content in solid soap remaining from petroleum refining such as diesel, gasoline, and kerosene, which should not be in cosmetics. The limit for mineral oil content in solid soap is $0.05 \%$. If the soap contains mineral oil, the soap's emulsion power will decrease and irritate the skin. 


\subsection{Preferred Test of Addition of Green Betel Leaf Extract to Organoleptic Solid Soap}

The hedonic test is a consumer acceptance test to measure the level of preference for a product. The results of organoleptic testing were observed from natural antioxidant soap with the addition of green betel leaf extract and citronella, namely color, aroma, and shape. The test was carried out by 30 Sriwijaya State Polytechnic students who responded about their preferences for the color, aroma, and shape of green betel leaf extract soap and citronella. Three graphs show the number of panelists' ratings of soap products.

a. Color preference test

The color preference test can be seen in Figure 11 below:

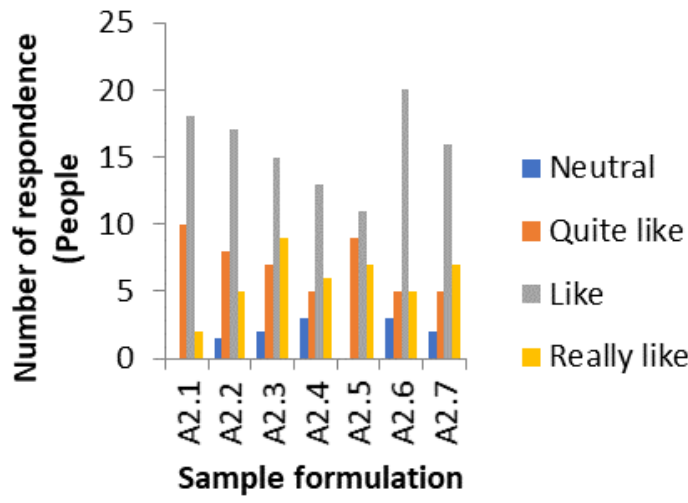

Figure 11 Color Preference Test on Solid Soap

It can be seen in the graph of the panelists' preference for the color of natural antioxidant soap, green betel leaf, and citronella. The most are in the sample formulation A26 with the addition of green betel leaf extract and citronella in a ratio of $(2.5: 2.5)$ gr with a yellowish-brown color. Meanwhile, the highest level of liking was in the sample formulation A23 with the addition of $2.5 \mathrm{~g}$ of citronella extract with a yellowish color. The difference in the color of the soap between treatments was not too different, namely pale yellow. The color of solid soap without adding betel leaf extract and citronella is milky white, while green betel leaf extract and citronella are brownish-yellow. The more the green betel leaf extract, the color of the soap will be brown or darker, while the more addition of citronella extract, the color of the soap will be more yellowish [14].

b. Test your preference for the scent

The preference test for aroma was carried out for two weeks on 30 panelists. Observation of aroma in the first week of all formulas still had a distinctive aroma of green betel leaf extract and citronella. The second week, the aroma began to disappear because the soap sample storage container was not tightly closed and caused the aroma of green betel leaf extract and citronella to evaporate. The test of preference for aroma can be seen in Figure 12

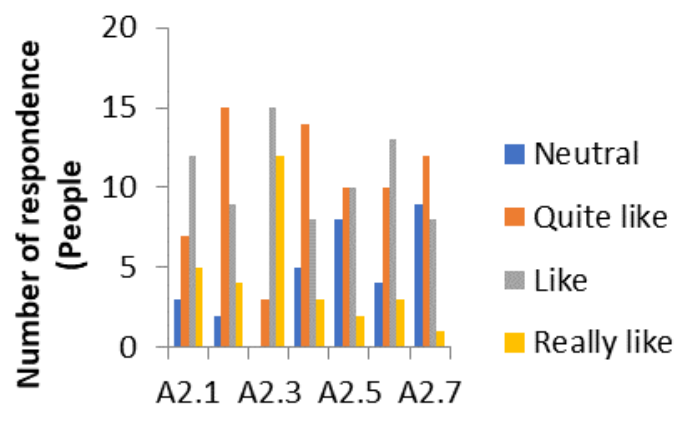

Sample formulation

Figure 12 Test the Likelihood of Smell on Solid Soap

As for the aroma test of natural antioxidant solid soap from green betel leaf extract and citronella, the formulation with the highest level of liking was in sample A23 with the addition of $2.5 \mathrm{~g}$ of citronella extract, and the highest liking was in sample A23 with the addition of citronella leaf extract. Fragrant as much as $2.5 \mathrm{~g}$.

c. Test of liking for shapes

The preference test for the shape of the solid soap all had the same shape, namely the shape of a rose, which of the 30 panelists all liked the form of solid soap from green betel extract and citronella. Therefore, from organoleptic tests on color, aroma, and shape, it can be concluded that from all existing formulas, the formula that is most accepted by the general public is formula A23 (addition of citronella leaf extract $2.5 \mathrm{~g}$ ) because the formula has an attractive yellowish color and the scent of citronella is not too strong.

\subsection{Test Results of Antioxidant Solid Soap Bacteria from Green Betel Leaf Extract and Fragrant Lemongrass}

To determine the ability of green betel leaf extract and citronella as natural antioxidants in soap, a comparison between unwashed hands, hands washed with sample soap, and hands washed with comparison soap (soap X) was carried out. Bacterial growth was observed for three days. Bacterial test results can be seen in the appendix.

From these data, it can be seen qualitatively that the number of bacteria on hands washed with samples of green betel leaf soap and citronella, the number of bacteria that grow is less compared to not washing 
hands. Compared to soap, the bacteria growth was reduced less than the sample soap of green betel leaf extract and lemongrass. The comparison soap is used as a common commercial soap as the best antioxidant soap for handwashing that has been clinically tested. However, samples of green betel leaf extract and citronella were also quite effective in killing bacteria. The reduced number can see colonies on agar that were scratched using hands washed with soap samples, which proves that green betel leaf extract and citronella have a role as an antibacterial against Staphylococcus aureus bacteria with strong effectiveness because they contain essential oils with bethel phenol and its derivatives which can inhibit bacterial growth so that it can be used in health products. For example, antioxidant soap.

The antibacterial power of essential oil of green betel leaf and citronella is caused by phenolic compounds and their derivatives (kavikol), denoting bacterial cell proteins [15]. Phenol can damage cell membranes, inactivate enzymes, and denature proteins to damage the cell wall due to a decrease. It causes the bacteria to be unable to maintain their original shape, causing damage to the bacterial cell wall. So that soap containing natural antioxidants from green betel leaf and citronella can kill bacteria.

\subsection{Comparison of Antioxidant Solid Soap Formulation Results Natural from Green Betel Leaf Extract and Fragrant Lemongrass}

Optimization of formulation Making solid soap with the addition of natural antioxidants, green betel leaf extract, and citronella aims to determine the formulation of green betel leaf and citronella antioxidant soap in accordance with SNI 06-35321994 standards. The comparison of making betel leaf soap from previous studies can be seen in Table 2 .

Table 2. Observation Results of Bacterial Growth Natural Antioxidant Soap Extract of Green Betel Leaf and Fragrant Lemongrass

\begin{tabular}{ccc}
\hline Without soap & $\begin{array}{c}\text { Soap betle } \\
\text { leaf and } \\
\text { citronella }\end{array}$ & $\begin{array}{c}\text { Soap X } \\
\text { (comparison) }\end{array}$ \\
\hline
\end{tabular}

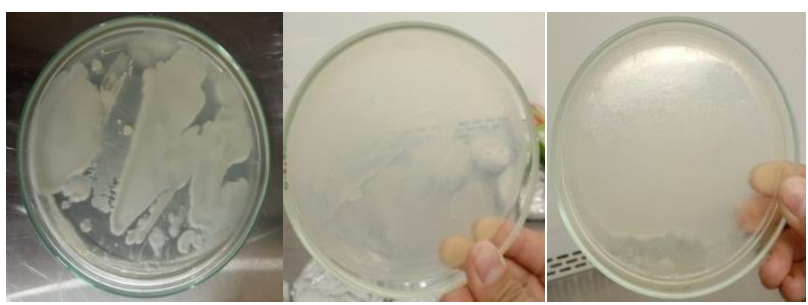

\subsection{Comparison of Formulation Results for Making Natural Antiseptic Solid Soap}

Optimization of formulation Making solid soap with the addition of natural antiseptic agent betel leaf extract aims to determine the formulation of antiseptic soap-making betel leaf following the standards of SNI 06-3532-1994. A comparison of the manufacture of betel leaf soap from previous studies can be seen in Table 3.

Table 3. Comparison of Making Green Betel Leaf Solid Soap and Fragrant Lemongrass

\begin{tabular}{|c|c|c|c|c|c|c|c|c|c|}
\hline \multirow{2}{*}{$\begin{array}{l}\text { Best } \\
\text { Formula }\end{array}$} & Additives & \multicolumn{7}{|c|}{ Soap Quality Test } & \multirow[t]{2}{*}{ Ref } \\
\hline & & $\mathrm{pH}$ & $\begin{array}{l}\text { Water } \\
(\%)\end{array}$ & $\begin{array}{l}\text { Alkali } \\
(\%)\end{array}$ & $\begin{array}{l}\text { FFA } \\
(\%)\end{array}$ & $\begin{array}{l}\text { Mineral } \\
\text { Oil }\end{array}$ & $\begin{array}{l}\text { Organolepti } \\
\text { c }\end{array}$ & $\begin{array}{l}\text { Bacter } \\
\text { ia Test }\end{array}$ & \\
\hline $\begin{array}{c}\text { VCO oil } \\
(30 \mathrm{ml})\end{array}$ & $\begin{array}{c}\text { Betel leaf } \\
\text { extract }\end{array}$ & 10 & - & 0.083 & - & - & - & $\begin{array}{l}\text { Inhibiti } \\
\text { on }\end{array}$ & [16] \\
\hline $\begin{array}{l}\text { Palm oil: } \\
\text { Olive oil: } \\
\text { VCO } \\
(10: 20: 20)\end{array}$ & $\begin{array}{c}\text { Betel leaf } \\
\text { extract } \\
(3 \text { gr })\end{array}$ & 11 & 14.2 & 0.052 & 0.1845 & Negatif & $\begin{array}{c}\text { Colour \& } \\
\text { scent }\end{array}$ & Inhibition & [17] \\
\hline $\begin{array}{l}\text { Olive } \\
\text { oil } \\
(30 \mathrm{ml})\end{array}$ & $\begin{array}{l}\text { Citronella } \\
\text { extract } \\
(18 \text { dan } 24 \\
\text { gr })\end{array}$ & 11 & - & $\begin{array}{c}0.1 ; \\
0.8\end{array}$ & - & - & $\begin{array}{l}\text { Colour } \\
\& \\
\text { scent }\end{array}$ & - & [18] \\
\hline
\end{tabular}




\begin{tabular}{|c|c|c|c|c|c|c|c|c|c|}
\hline $\begin{array}{l}\text { Palm oil: } \\
\text { Olive oil: } \\
\text { VCO } \\
(10: 20: 20)\end{array}$ & $\begin{array}{c}\text { Betle leaf } \\
\text { extract } n \\
\text { Citronella } \\
\text { extract } \\
(0: 2,5) \mathrm{gr} n \\
(2,5: 0) \mathrm{gr}\end{array}$ & 10 & 14.8 & 0.08 & 0.0512 & Negatif & $\begin{array}{c}\text { Colour, } \\
\text { scent } n \\
\text { shape }\end{array}$ & $\begin{array}{l}\text { Inhibitio } \\
\mathrm{n}\end{array}$ & $\begin{array}{l}\text { This } \\
\text { study }\end{array}$ \\
\hline
\end{tabular}

The formulation of soap making using natural antioxidants of green betel leaf and citronella includes several quality tests. For example, for the $\mathrm{pH}$ test in research [16], the resulting $\mathrm{pH}$ is 10 [17], the $\mathrm{pH}$ value is 11 [18], the $\mathrm{pH}$ value is 11 and 10 , while for the current research the $\mathrm{pH}$ value is 10 .

The next quality test is water content. In research[17], the water content value obtained is $14.2 \%$, and the water content value obtained is $14.8 \%$ for research conducted now. High water content in the current study was due to the absence of initial treatment on green betel leaves and citronella, namely direct drying under the sun. In the research free alkaline level test, the alkali content was $0.083 \%$ with a $2.5 \%$ extract. The alkali content obtained was $0.052 \%$ with $3 \mathrm{gr}$ extract. Thus, the alkali obtained was $0.10 \%$ and $0.8 \%$. For the current research, the free alkali content was $0.08 \%$ with the addition of $2.5 \mathrm{gr}$ lemongrass extract capable of reacting with alkali $(\mathrm{NaOH})$. The free alkali content (alkali which does not react) is small, wherein the study the more extracts added, the lower the alkali content.

\section{CONCLUSION}

In green betel leaf essential oil, the content that is useful as an antioxidant is 1-2\% phenol content, and citronella essential oil contains $32-45 \%$ citronellal and $12-18 \%$ geraniol content that is useful as an antioxidant. The addition of green betel leaf extract and citronella in solid soap affects the physical form of aroma and color and the quality of the soap produced where the higher the addition of green betel leaf extract and citronella, the water content and free fatty acids increase because the water content is directly proportional to the FFA, the high water content is caused by too much palm oil being used. Meanwhile, for alkali, the higher the addition of extract, the level will decrease since the extracts of green betel leaf and citronella can react with the alkali in the soap $(\mathrm{NaOH})$ so that the alkali that is not bound to free alkali has a small value of free alkali. The soap formula with the best variations in oil composition and according to the quality standard of SNI 06-3536-1994 is the composition of palm oil, $\mathrm{VCO}$, and olive oil with sample formulation A2 with a ratio of $(1: 2: 2)$ gr. The sample formulation for making solid soap with the addition of green betel leaf extract and citronella as an antioxidant which has resulted in accordance with the Indonesian National Standard (SNI) 06-3536-1994, is the sample formulation A23 and A24 with a composition of green betel leaf extract and citronella as much as (0:2.5) grand (2.5:0) gr.

\section{ACKNOWLEDGMENTS}

The authors acknowledge funded by the Directorate General of Higher Education, Ministry of Education and Culture, in accordance with the Agreement for the Implementation of Research Assignment of Innovation Assignments.

Number: 3626/PL6.4.2/SK/2021 dated 11 May 2021

\section{REFERENCES}

[1] S.R. Gundala, R. Aneja, Piper betel leaf: A reservoir of potential xenohormetic nutraceuticals with cancer-fighting properties, Cancer Prev. Res. 7 (2014) 477-486. https://doi.org/10.1158/1940-6207.CAPR-130355 .

[2] J. Edianta, N. Fauzi, M. Naibaho, F.S. Arsyad, I. Royani, Review of the effectiveness of plant media extracts in barium hexaferrite magnets (Bafe12o19), Sci. Technol. Indones. 6 (2021) 39-52.

https://doi.org/10.26554/STI.2021.6.2.39-52.

[3] H.-J. Choi, K. Sowndhararajan, N.-G. Cho, K.H. Hwang, S.-J. Koo, S. Kim, Evaluation of Herbicidal Potential of Essential Oils and their Components under In vitro and Greenhouse Experiments, Weed Turfgrass Sci. 4 (2015) 321-329. https://doi.org/10.5660/wts.2015.4.4.321.

[4] O. Avoseh, O. Oyedeji, P. Rungqu, B. NkehChungag, A. Oyedeji, Cymbopogon species; ethnopharmacology, phytochemistry and the pharmacological importance, Molecules. 20 (2015) $7438-7453$ https://doi.org/10.3390/molecules20057438.

[5] A.N. Panche, A.D. Diwan, S.R. Chandra, Flavonoids: An overview, J. Nutr. Sci. 5 (2016). https://doi.org/10.1017/jns.2016.41.

[6] D. Tozoni, J. Zacaria, R. Vanderlinde, A.P.L. Delamare, S. Echeverrigaray, Degradation of citronellol, citronellal and citronellyl acetate by Pseudomonas mendocina IBPse 105, Electron. J. Biotechnol. 13 (2010) 1-7. https://doi.org/10.2225/vol13-issue2-fulltext-8.

[7] A. Lichterfeld-Kottner, M. El Genedy, N. 
Lahmann, U. Blume-Peytavi, A. Büscher, J. Kottner, Maintaining skin integrity in the aged: A systematic review, Int. J. Nurs. Stud. 103 (2020) 103509. https://doi.org/10.1016/j.ijnurstu.2019.103509.

[8] C. Babii, L.G. Bahrin, A.N. Neagu, I. Gostin, M. Mihasan, L.M. Birsa, M. Stefan, Antibacterial activity and proposed action mechanism of a new class of synthetic tricyclic flavonoids, J. Appl. Microbiol. 120 (2016) 630637. https://doi.org/10.1111/jam.13048.

[9] L. Baranda, R. González-Amaro, B. TorresAlvarez, C. Alvarez, V. Ramírez, Correlation between $\mathrm{pH}$ and irritant effect of cleansers marketed for dry skin, Int. J. Dermatol. 41 (2002) 494-499. https://doi.org/10.1046/j.13654362.2002.01555.x.

[10] Iriany, L. Sukeksi, V. Diana, Taslim, Preparation and Characterization of Coconut Oil Based Soap with Kaolin as Filler, J. Phys. Conf. Ser. 1542 (2020). https://doi.org/10.1088/17426596/1542/1/012046.

[11] S.N. Naik, V. V. Goud, P.K. Rout, A.K. Dalai, Production of first and second generation biofuels: A comprehensive review, Renew. Sustain. Energy Rev. 14 (2010) 578-597. https://doi.org/10.1016/j.rser.2009.10.003.

[12] S. Poongulali, M. Sundararaman, Antimycobacterial, anticandidal and antioxidant properties of Terminalia catappa and analysis of their bioactive chemicals., Int. J. Pharm. Biol. Sci. 6 (2016) 69-83.

[13] D.J. McClements, J. Rao, Food-Grade nanoemulsions: Formulation, fabrication, properties, performance, Biological fate, and Potential Toxicity, Crit. Rev. Food Sci. Nutr. 51 (2011) 285-330. https://doi.org/10.1080/10408398.2011.559558.

[14] I. Hadning, P. Kurnyaningtyas, M.T. Ghozali, The Formulation of Lotion Preparations of Betel Leaf Extract (Piper betle), J. Fundam. Appl. Pharm. Sci. $\quad 1 \quad$ (2020) https://doi.org/10.18196/jfaps.010104.

[15] M. Madhumita, P. Guha, A. Nag, Extraction of betel leaves (Piper betle L.) essential oil and its bio-actives identification: Process optimization, GC-MS analysis and anti-microbial activity, Ind. Crops Prod. 138 (2019) 111578. https://doi.org/10.1016/j.indcrop.2019.111578.

[16] W.T. Agusta, OPTIMASI FORMULA SABUN CAIR ANTIBAKTERI EKSTRAK ETANOL DAUN SIRIH MERAH (Piper Crocatum Ruiz \&Pav ) DENGAN VARIASI KONSENTRASI VIRGIN COCONUT OIL (VCO) DAN KALIUM HIDROKSIDA, 2016.

[17] M. Aznury, I. Hajar, A. Serlina, J.T. Kimia, P. Negeri, S. Srijaya, N. Bukit, B. Palembang, OPTIMASI FORMULA PEMBUATAN SABUN PADAT ANTISEPTIK ALAMI DENGAN PENAMBAHAN EKSTRAK DAUN SIRIH HIJAU (Piper betle L) OPTIMIZING THE FORMULA FOR MAKING NATURAL ANTISEPTIC SOAP WITH THE ADDITION OF GREEN BETEL LEAF (Piper betle L), J. Kinet. 12 (2021) 5159.

https://jurnal.polsri.ac.id/index.php/kimia/index 51.

[18] R. Rinaldi, F. Fauziah, R. Mastura, FORMULASI DAN UJI DAYA HAMBAT SABUN CAIR EKSTRAK ETANOL SERAI WANGI (Cymbopogon nardus L) TERHADAP PERTUMBUHAN Staplylococcus aureus, J. Ris. Kefarmasian Indones. 3 (2021) 45-57. https://doi.org/10.33759/jrki.v3i1.115. 